\title{
The Moderating Role of Openness to Experience on the Relationship between Concientiousness, Exraversion and Universal-Diverse Orientation in Counseling Students
}

\author{
Prof.Dr. Nazmiye Çivitci \\ Pamukkale University-Turkey \\ ncivitci@pau.edu.tr
}

\begin{abstract}
:
The aim of this study is to examine whether there is a moderating role of openness to experience in the relationship between the Universal-Diverse Orientation (UDO), and the conscientiousness and extraversion of counseling students. The study was conducted with 377 counseling undergraduate students attending a public university in the west of Turkey. Adjective Based Personality Scale and Short Form of the Miville-Guzman Universality-Diversity Scale were used to collect data of the study. The moderating effects of openness to experience in the relationship between conscientiousness and extraversion, and UDO was examined by Baron and Kenny's (1986) moderating model. Regression analysis procedures based on this moderating model were used. The findings of the study indicated that openness to experience had a moderating role in the relation between their UDO, and conscientiousness and extraversion. As a result, the findings of the present study highlights that openness to experience has a moderating role in reducing the negative effects of conscientiousness and extraversion on the UDO.
\end{abstract}

Keywords: Universal-diverse orientation, personality traits, openness to experience conscientiousness, extraversion

DOI: 10.19160/ijer.776966

E-International Journal of Educational Research, Vol: 11, No: 2, 2020, pp. 1-15

\section{Suggested Citation}

Çivitci, N. (2020). The moderating role of openness to experience on the relationship between concientiousness, exraversion and universal-diverse orientation in counseling students, E-International Journal of Educational Research, Vol 11, No 2, 2020, pp. 1-15, DOI: 10.19160/ijer.776966 


\section{INTRODUCTION}

It is important that the societies gaining more and more pluralism are reflected in the counseling area. In recent years, it has been observed that the effects of pluralism have increased in counseling theories and practices, and multicultural issues such as the attitudes of counselors towards differences and the ability to work with clients from different cultures have been the focus of attention. The necessity of working with diverse clients is based on the acceptance and awareness of the similarities and differences among people (Yeh \& Arora, 2003). As Vontress (1988) has also underlined, process counselors are required to accept and respect the cultural diversities for an effective therapeutic relationship along with allying to the similarities of being a human that clients bring to the counseling process (as cited in Ponterotto, 2008, p.124). Counselors need to be sensitive to the collective perceptions and experiences of the clients as well as to their individual perceptions and experiences (Trusty, Davis \& Looby, 2002). In this regard, Universal-Diverse Orientation (UDO) that "reflects the attitudes of awareness and acceptance toward the similarities and differences among people" (Miville et al., 1999, p.291), gains importance. The studies indicate that UDO has a positive correlation with empathy (Miville et al., 2006), ethno cultural empathy (Wang et al., 2003), the self-perceived multicultural counseling competence (Constantine et al., 2001) and a negative correlation with dogmatism and homophobia (Miville et al., 1999). Some interesting findings have also been revealed in the research studies examining how UDO influences counseling process. For instance, a study by Stracuzzi, Mohr and Fuertes (2011) shows that counselors' UDO is positively associated with their perceptions of gay and bisexual male clients regarding the working alliance, session depth, and session smoothness. In the same vein, another research (Harbin, 2004) reveals a negative correlation between the counselors' UDO and their countertransference reactions including anger and anxiety toward clients with different racial origins. Based on the research findings above, it can be said that UDO has a crucial role for the therapeutic effectiveness of the counselors and promoting effective relations especially with the diverse clients. Given the role of UDO in therapeutic efficacy, understanding the factors contributing to the UDO of counselors gains more importance.

Another variable that plays an important role in the effectiveness of the counseling process is the personality traits of the counselors. Counselor educators heavily emphasize the role of counselors' personality traits in the effectiveness of counseling. It is even reported that the personality traits of counselors are more influential than the theories and techniques they use in their relations with the clients (Crews et al., 2005). It is observed that the personality which plays a significant role in the therapeutic efficacy of the counselor is also a factor contributing to the UDO. Some previous studies demonstrate that UDO is positively correlated with openness to experience (Thompson, Brossart, Carlozzi \& Miville, 2002; Strauss \& Connerley, 2003; Han \& Pistole, 2017), agreeableness (Strauss \& Connerley, 2003; Han \& Pistole, 2017); and healthy attributes of personality (Roberts, Laux, \& Burck, 2005). Openness to experience particularly stands out as a strong predictive of UDO (Thompson et al., 2002; Strauss \& Connerley, 2003; Han \& Pistole, 2017). Openness to experience can be identified as the disposition toward curiosity, cultural sophistication, intelligence flexibility and openness to new feelings and ideas (Chamorro-Premuzic, 2007). Individuals open to experience have a wide range of interests (Rolland, 2002, p. 8), a high level of intellectual interests and aesthetic sensitivity (ChamorroPremuzic, 2007) and they are not conservative (Kail \& Cavanaugh, 2008). Furthermore, the related literature points out that openness to experience is negatively correlated with prejudice (Ekehammar \& Akrami, 2003; Flynn, 2005; Ekehammar \& Akrami, 2007) and positively correlated with positive attitudes toward immigrants (Gallego \& Pardos-Prado, 2013), multicultural counseling competency (Moore-Thomas, 1998), intercultural sensitivity (Aydın \& Şahin, 2017) and attitudes toward equal opportunities for immigrants (Ackermann \& Ackermann, 2015). All these characteristics of openness to experience refer to the positive attitudes toward diversity; 
and clarify that openness is a strong predictor of UDO. In addition, findings from the research conducted by Dinesen, Klemmensen and Norgaard (2016) show that openness to experience contributes positively to the attitudes toward migrants by reducing the influence of factors such as cultural and economic threats on the attitudes toward migrants. This finding also reveals the indirect effects along with direct effects of openness to experience on attitudes toward diversity. Positive effects of openness to experience on the attitudes toward diversity make it more valuable for the counselors. In the counseling process, openness to experience is considered as an essential dimension for the counselors' ability to deal with the differences such as gender and race (Leong \& Bhagwat 2001, p. 258).

As another component of the personality, conscientiousness refers to self-discipline, responsibility, competence, order, leadership (Chamorro-Premuzic, 2007, p.27), being hardworking, ambitious and persevering (McCrae, \& Costa, 1987). Among personality dimensions, it is the most related factor with the academic and job performance (McCrae, 2004). Although conscientiousness has positive contributions to the academic and work performances, it cannot be said that it positively affects the attitudes toward diversity. The research on the relationship between the conscientiousness and attitudes toward diversity indicates a positive correlation between conscientiousness and negative attitudes toward the immigrants (Gallego \& Pardos-Prado, 2013); and between conscientiousness and the attitudes toward equal opportunities for immigrants (Ackermann \& Ackermann, 2015). Moreover, conscientiousness is not considered as a personal trait promoting positive attitudes toward diversity as it is not associated with UDO (Thompson et al., 2002; Strauss \& Connerley, 2003) and intercultural sensitivity (Aydın \& Şahin, 2017).

Extraversion is the other personality trait that was addressed in the current research. The main characteristics of extravert individuals are warmth, assertiveness, positive emotions, excitement seeking and social dominance (Chamorro-Premuzic, 2007, p.27). When compared to those of open and conscient individuals, the attitudes toward diversity of extraverts are more controversial. As extraversion is not linked to UDO (Thompson et al., 2002, Strauss \& Connerley, 2003) and intercultural sensitivity (Aydın \& Şahin, 2017), it does not have strong effects on the attitudes to diversity. However, it is remarkable that extraversion is related (Carney, Jost, Gosling \& Potter, 2008; Gerber, Huber, Doherty, Dowling \& Ha, 2010) to negative attitudes toward immigrants (Gallego \& Pardos-Prado, 2013) and conservatism which refers to the acceptance of inequality (Hirsh, Young, Xu \& Peterson, 2010).

Among personality traits, openness to experience holds the most consistent and powerful positive relations with the attitudes toward diversity. In contrast to openness to experience, conscientiousness and extraversion are observed to be negatively related with the attitudes toward diversity. Given the strong relationship between the attitudes toward diversity and openness to experience, it is expected that openness functions as a buffer by reducing the negative effects of conscientiousness and extraversion on the UDO. In other words, it is foreseen that openness to experience will play a moderating role for the relationship between the UDO, and conscientiousness and extraversion. The aim of the current study is to examine whether there is a moderating role of openness to experience in the relationship between the UDO, and the conscientiousness and extraversion of counseling students.

\section{METHOD}

\section{Participants}

The present study was conducted with 377 counseling undergraduate students attending a public university in the west of Turkey. The students voluntarily participated in the study. 109 of the participants were males (29\%) and 268 of them were females $(71 \%)$, and their ages varied between 18 and $25(M=20.38, S D=1.75)$. 


\section{Measures}

The Miville-Guzman Universality-Diversity Scale- Short Form: The Miville-Guzman Universality-Diversity Scale- Short Form (M-GUDS-S) developed by Fuertes et. al. (2000) was adapted to Turkish by Çivitci (2014). As a Likert-type scale, M-GUDS-S involves 15 items. MGUDS-S includes three sub-scales called Diversity Contact, Relativistic Appreciation and Comfort with Differences. Exploratory Factor Analysis was performed to specify the construct validity of the Turkish version of M-GUDS-S; and a three-factor construct was found. This three-factor construct was supported by Confirmatory Factor Analysis (CFA). Based on CFA, fit indexes were calculated as RMSEA $=.055, \mathrm{GFI}=.94, \mathrm{AGFI}=.92, \mathrm{CFI}=.96, \mathrm{NFI}=.93$ and NNFI $=.95$. Criterionrelated validity of M-GUDS-S was tested through Multicultural Personality Scale. The scores from both of the scales were correlated significantly and positively. In the reliability study of $\mathrm{M}$ GUDS-S, Cronbach Alpha coefficient was found to be .75 for the total score; test re-test reliability coefficient was also found as .92 for the total score. Cronbach Alpha coefficient obtained in the current study was .78 for the total score.

Adjective-Based Personality Scale (ABPS): It was developed by Bacanlı, Ilhan and Aslan (2009) based on the Five Factor Theory. ABPS, a Likert-type scale, consists of 40 items which are antonym pairs of adjectives. Findings of the factor analysis indicated a five-factor structures; which are Extraversion, Agreeableness, Conscientiousness, Emotional Stability and Openness to Experience. Five factors account for $52.63 \%$ of the total variance. To test the concurrent validity of the ABPS, Sociotrophy Scale, Reaction to Conflicts Scale, Negative-Positive Emotion Scale and Trait Anxiety Inventory were employed. Significant correlations were found between the factors of the ABPS and these scales. The reliability of ABPS was tested via the analyses of test-retest and Cronbach Alpha coefficient. Reliability coefficients for each sub-scale figured out through test-retest analysis were computed as $.85, .86, .71, .85$ and .68 for Extroversion, Agreeableness, Conscientiousness, Emotional Stability and Openness to Experience. For those five factors, Cronbach Alpha coefficients were $.89, .87, .88, .73$ and .80 respectively. Cronbach Alpha coefficients obtained in the current study were .89 for Extraversion .80 for Conscientiousness and .77 for Openness to Experience.

\section{Data Analysis}

The moderating effects of openness to experience in the relationship between conscientiousness and extraversion, and UDO was examined by Baron and Kenny's (1986) moderating model. Regression analysis procedures based on this moderating model were used.

\section{Procedure}

Data collection tools of the study were administered to the participants by the researcher in the classroom. The participants were informed about the purpose of the study and the confidentiality of the data gathered. The participants took part in the study on a voluntarily basis.

\section{FINDINGS}

Descriptive statistics and bivariate correlations for all variables are reported in Table 1. As shown in Table 1, there are significant correlations between all variables. Additionally, Kurtosis and Skewness values indicate normally distributed data. 
Table 1:

Correlation and descriptive statistics of all variables in the study

\begin{tabular}{lcccc}
\hline & 1 & 2 & 3 & 4 \\
\hline 1.UDO & - & & & \\
2. Conscientiousness & $.11^{\star}$ & - & & \\
3. Extraversion & $.35^{\star \star}$ & $.36^{\star \star}$ & - & - \\
4. Openness & $.59^{\star \star}$ & $.35^{\star \star}$ & $.68^{\star \star}$ & 43.79 \\
\hline Mean & 71.39 & 37.02 & 8.86 & 6.48 \\
SD & 7.48 & 6.81 & -.48 & -.61 \\
Skewness & -.37 & -.98 & -.02 & .36 \\
Kurtosis & .06 & 1.01 & & \\
\hline
\end{tabular}

** $p<0.01 \quad * p<0.05 \quad$ UDO: Universal-Diverse Orientation

To examine the moderating effects of openness to experience on the relationship between conscientiousness and extraversion, and UDO, hierarchical multiple regression procedures suggested by Baron and Kenny (1986) were applied, For predictor variables (conscientiousness and extraversion) $z$-scores were used to minimize multicollinearity problems between the interaction and the main effects (Frazier, Tix, \& Barron, 2004). In the first step of the hierarchical regression model, predictive variables (conscientiousness and extraversion) added to the regression model; in the second step, potential moderator variable (openness to experience) and in the third step, interaction variable (openness to experience $x$ conscientiousness and extraversion) were also added. Results of analysis for moderating effect of openness to experience on the relationships between conscientiousness and UDO are reported in Table 2.

Table 2:

Hierarchical regression analysis for moderating effect of openness to experience on the relationships between conscientiousness and UDO

\begin{tabular}{|c|c|c|c|c|c|c|c|c|c|}
\hline Variable & $B$ & SEB & $\beta$ & $t$ & $p$ & $R^{2}$ & $\Delta R 2$ & $F$ & $p$ \\
\hline \multicolumn{10}{|l|}{ Dependent variable: UDO } \\
\hline \multicolumn{10}{|l|}{ Step 1} \\
\hline Conscientiousness & .81 & .38 & .11 & 2.12 & .035 & .01 & .01 & 4.47 & .035 \\
\hline \multicolumn{10}{|l|}{ Step 2} \\
\hline Conscientiousness & -.82 & .33 & -.11 & -2.47 & .014 & \multirow{2}{*}{.36} & \multirow{2}{*}{.35} & \multirow{2}{*}{104.85} & \multirow{2}{*}{.000} \\
\hline Openness to Experience & 4.70 & .33 & .63 & 14.24 & .000 & & & & \\
\hline \multicolumn{10}{|l|}{ Step 3} \\
\hline Conscientiousness & -.72 & .33 & -.10 & -2.19 & .029 & & & & \\
\hline Openness to Experience & 4.90 & .34 & .65 & 14.57 & .000 & .37 & .01 & 73.20 & .000 \\
\hline UDO X Conscientiousness & .65 & .25 & .11 & 2.59 & .010 & & & & \\
\hline
\end{tabular}

UDO: Universal-Diverse Orientation

As shown in Table 2, there was a significant interaction between conscientiousness and openness to experience $[\beta=0.11, p<.01]$. The results indicated that openness to experience had a moderating effect on the relationship between conscientiousness and UDO. To determine the direction of this interaction, procedures drawn by Cohen, Cohen, West, and Aiken (2003) were followed. 


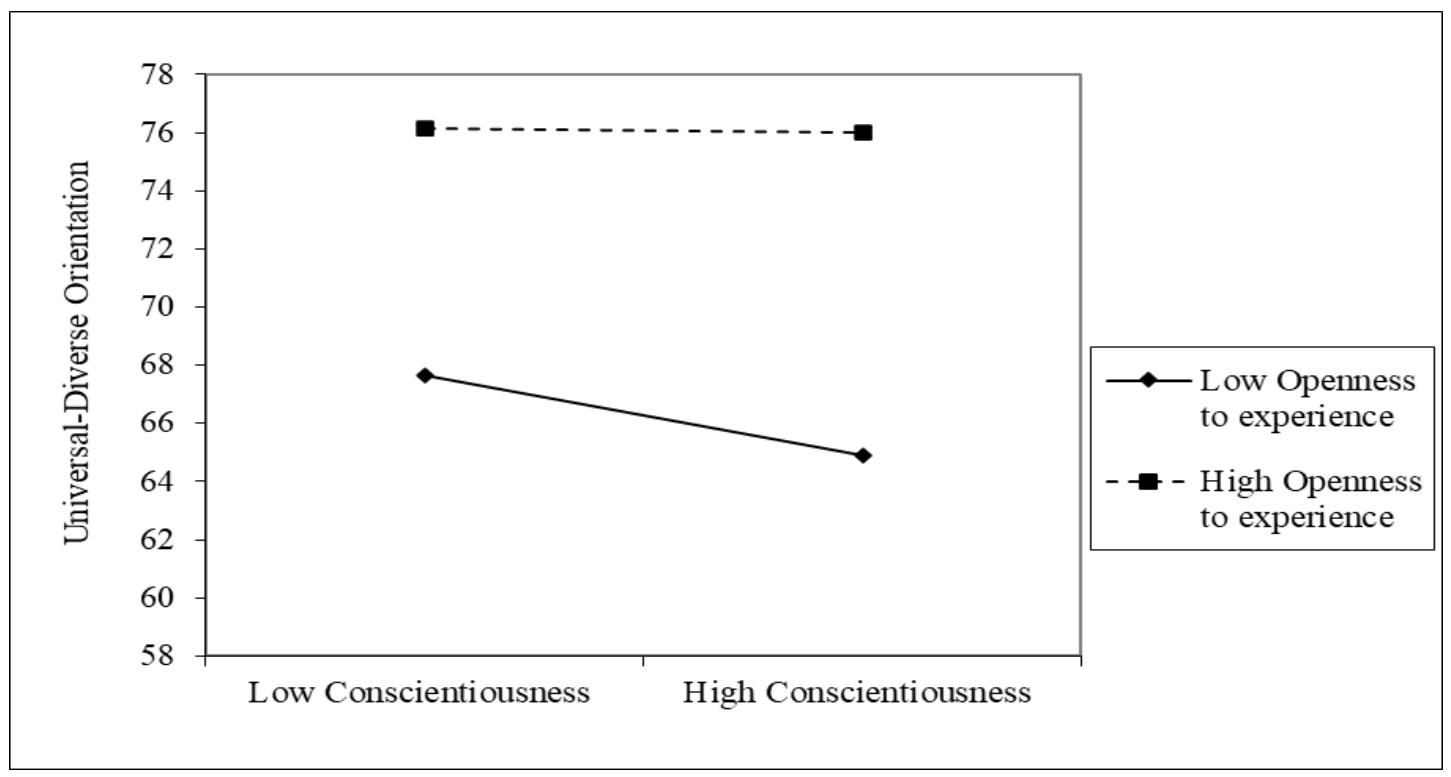

Figure 1. Openness to experience as a moderator of the relationship between conscientiousness and universal-diverse orientation

As seen in Figure 1, the effect of conscientiousness on the UDO varies according to the openness to experience level of students. As conscientiousness increases, UDO decreases in the students who have low openness to experience. However, UDO is more stable in the students who have high openness to experience.

Table 3:

Hierarchical regression analysis for moderating effect of openness to experience on the relationships between extraversion and UDO

\begin{tabular}{lccccccccc}
\hline Variable & $B$ & SEB & $\beta$ & $t$ & $p$ & $R^{2}$ & $\Delta R 2$ & $F$ & $p$ \\
\hline$\quad \begin{array}{l}\text { Dependent variable: UDO } \\
\quad\end{array}$ & & & & & & & & & \\
$\quad$ Step 1 & 2.62 & .36 & .35 & 7.24 & .000 & .12 & .12 & 52.43 & .000 \\
$\quad$ Extraversion & & & & & & & & & \\
$\quad$ Step 2 & -.72 & .42 & -.10 & -1.69 & .092 & & & & \\
$\quad$ Extraversion & 4.91 & .42 & .66 & 11.57 & .000 & .35 & .23 & 102.37 & .000 \\
$\quad$ Openness to Experience & & & & & & & & & \\
$\quad$ Step 3 & -.81 & .42 & -.11 & -1.91 & .057 & & & & \\
$\quad$ Extraversion & 5.29 & .45 & .71 & 11.86 & .000 & .36 & .01 & 71.55 & .000 \\
$\quad$ Openness to Experience & .69 & .26 & .12 & 2.60 & .010 & & & & \\
$\quad$ UDO X Extraversion & & & & & & & & & \\
\hline
\end{tabular}

UDO: Universal-Diverse Orientation

As seen in Table 3, there was a significant interaction between extroversion and openness to experience $[\beta=0.12, p<.01]$. The results of hierarchical regression analysis demonstrated that openness to experience had a moderating effect on the relationship between extraversion and UDO. 


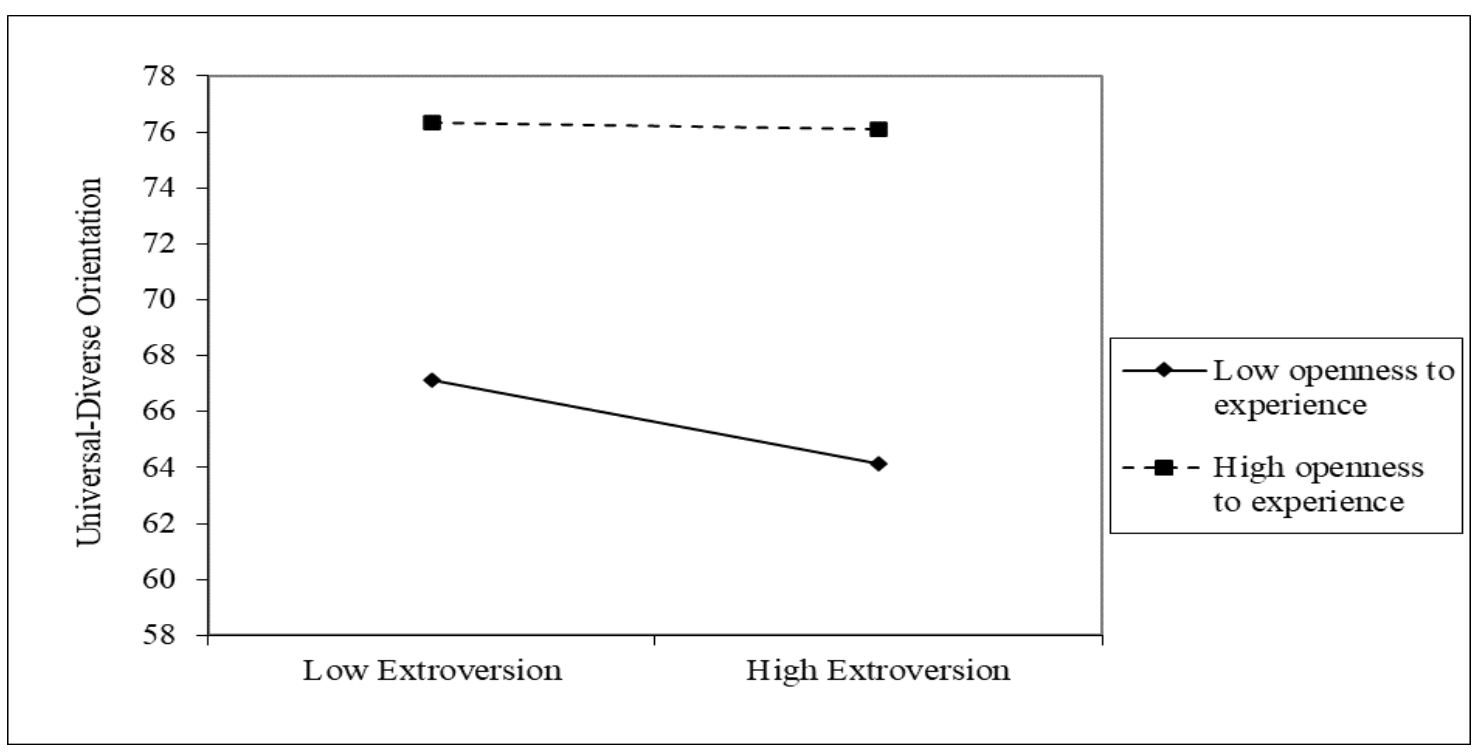

Figure 2. Openness to experience as a moderator of the relationship between extraversion and universaldiverse orientation

As indicated in Figure 2, as extroversion increases, UDO decreases in the students who have low openness to experience. In contrast, no such decrease was observed in the students who have high openness to experience.

\section{DISCUSSION}

The present study investigates the moderating role of openness to experiences in the relationship between the counseling students' UDO, and conscientiousness and extraversion. The findings of the study indicated that openness to experience had a moderating role in the relation between their UDO, and conscientiousness and extraversion.

Based on the findings, it was found out that openness to experience plays a moderating role in the relationship between UDO and conscientiousness. In other words, as conscientiousness increases, UDO decreases in the students who have low openness to experience. However, UDO is more stable in the students who have high openness to experience. In this case, it can be said that openness to experience acts as a buffer by reducing the negative effects of conscientiousness on UDO. The finding that positive attitudes toward diversity diminish as the level of conscientiousness rises is in line with the related literature. The studies examining the relationship between counseling students' personality and UDO (Thompson et al., 2002; Strauss \& Connerley, 2003) reveal that conscientiousness is not linked to UDO. It is pointed out that persons with high conscientiousness have negative attitudes toward immigrants (Gallego \& Pardos-Prado, 2013) and negative attitudes toward equal opportunities for immigrants (Ackermann \& Ackermann, 2015). As the level of conscientiousness gets higher, social conformity is observed to get promoted (Sibley \& Duckitt, 2008). In this regard, it is not easy to develop attitudes and behaviors toward diversity; independent of social judgments. Furthermore, persons with high conscientiousness value the traditions. The importance they attach to traditionalism can have an impact on the development of conservative attitudes (Mondak, 2010). A great number of studies probing into the relationship between personality and political orientation (Carney et al., 2008, Gerber et al., 2010; Hirsh et al., 2010) put forth that conscient people are more conservative. It is noteworthy that conscientiousness is positively associated with conservatism characterized by the acceptance of inequality and resistance to change (Hirsh et al., 2010). Conservative and traditionalist characteristics of conscient people lead to perceive the diversity as a threat for their traditions. On the contrary to the conscientiousness, openness to experience is positively correlated with the nonconventional 
(Weiten, 2010) and liberal attitudes (Carney et al., 2008; Gerber et al., 2010; Hirsh et al., 2010) promoting positive attitudes to diversity. Openness to experience is positively correlated with UDO (Thompson et al., 2002; Strauss \& Connerley, 2003), favorable attitudes toward homosexuality (Shackelford \& Besser, 2007), intercultural sensitivity (Aydın \& Şahin, 2017), positive attitudes toward immigrants (Gallego \& Pardos-Prado, 2013) and positive attitudes toward equal opportunities for immigrants (Ackermann \& Ackermann, 2015), and negatively correlated with prejudice (Ekehammar \& Akrami, 2003; Flynn, 2005). These characteristics of openness can contribute to the reduction of the negative effects of conscientiousness on the attitudes towards diversity. The combination of conscientiousness and openness to experience can be deduced to facilitate the interactions with differences. The findings of the research carried out by Ackermann and Ackermann (2015) support those of the current research. According to the results of the study, highly conscientious individuals' attitudes toward equal opportunities for immigrants differ depending on the homogenous or heterogeneous environment they live in. That is, living in an environment of different nationality neighbors diminishes the negative effects of conscientiousness on the attitudes toward equal opportunities for immigrants (Ackermann \& Ackermann, 2015). These findings on conscientiousness also clarify the moderating effect of openness to experience on the relationship between conscientiousness and UDO. According to these findings, it can be said that negative attitudes of conscient people toward diversity are not permanent. It is evident that some factors that contribute to the development of more flexible and tolerant attitudes can have an impact on the negative attitudes of individuals with high conscientiousness toward diversity.

Another finding of this study demonstrated that openness to experience has a moderating effect on the relationship between extraversion and UDO. According to this finding, as extraversion increases, UDO decreases in the students who have low openness to experience. In contrast, no such decrease was observed in the students who have high openness to experience. In other words, openness to experience functions as a buffer by reducing the negative effects of extroversion on the UDO. Sociable and relationship-oriented characteristics of extravert individuals (McCrae \& Löckenhoff, 2010) seem to facilitate their interaction with differences. Positive emotions and warmth, two of the facets of extraversion, promote the positive attitudes towards diversity as these facets are positively correlated with UDO (Han \& Pistole, 2017), and negatively correlated with the prejudice (Ekehammar \& Akrami, 2007). On the other hand, assertiveness and activity facets of extraversion are not linked to prejudice (Ekehammar \& Akrami, 2007). In addition, it is remarkable that there is a positive correlation between extraversion, and negative attitudes toward immigrants (Gallego \& Pardos-Prado, 2013) and conservatism enhancing the negative attitudes toward diversity (Carney et al., 2008; Gerber et al., 2010). When all the aspects of extraversion are evaluated together, it can be concluded that some of its facets facilitate interaction with differences, while some others make it difficult to interact with differences. Openness to experience can be said to act as a buffer to diminish these difficulties. Given the positive and consistent effects of openness to experience on the attitudes toward diversity, it is not surprising that it can decrease the negative effects of extraversion on attitudes toward diversity. The findings of the present study are supported by those of a study conducted by Turner, Dhont, Hewstone, Prestwitch and Vonofakou (2014). According to the findings of that research, increases in cross-group friendship and lowering the levels of intergroup anxiety reduce the negative effects of extroversion on the outgroup attitude.

As a result, the findings of the present study highlights that openness to experience has a moderating role in reducing the negative effects of conscientiousness and extraversion on the UDO. Openness to experience can be said to facilitate more flexible and tolerant attitudes toward diversity. The findings can be regarded as additional evidence to reveal the indirect effects of openness to experience on the attitudes to diversity. The findings can also be said to 
have significant results for counselor education. It is considered that raising counseling students' awareness on the contribution of personality traits to the UDO would be effective in selfexploration and acquiring insights. Their experiences in education process are crucial for creating awareness. Particularly in the counseling supervision process, it is important to include experiences raising their awareness regarding how personal traits affect their relations with diverse clients.

Findings of this study need to be evaluated in terms of some limitations. First, findings are limited to the data obtained through self-report scales. The fact that this research was conducted on counseling students at a public university can be considered as a limitation for the generalizability of the findings. However, future studies on different samplings can contribute to the generalizability of the research findings. Moreover, the present investigation does not deal with the facets (assertiveness, warmth, etc.) of the related personality traits (openness to experience, conscientiousness and extraversion). More comprehensive findings are expected to emerge at future research studies involving the facets of personality traits.

\section{REFERENCES}

Ackermann, K. \& Ackermann, M. (2015). The big five in context: Personality, diversity and attitudes toward equal opportunities for immigrants in Switzerland. Swiss Political Science Review, 21(3), 396-418. doi.org/10.1111/spsr.12170

Aydın, B. \& Şahin, M. (2017). Psikolojik danışman adaylarında kültürel duyarlılı̆ı yordayan bazı değişkenler [Some varibles predicting the cultural sensitivity in counselor candidates]. Buca Eğitim Fakültesi Dergisi- Journal of Buca Education Faculty, 43, 64-77. Retrieved from http://dergipark.gov.tr/deubefd/issue/35767/399873

Bacanlı, H., Illhan, T. \& Aslan S. (2009). Beş faktör kuramına dayalı bir kişilik ölçeğinin geliştirilmesi: sıfatlara dayalı kişilik testi (SDKT) [Development of a personality scale based on five factor theory: adjectıve based personality test (ABPT)]. Türk Eğitim Bilimleri DergisiThe Journal of Turkish Educational Sciences, 7(2), 261-279. Retrieved from http://dergipark.gov.tr/download/ article-file/256271

Baron, R.M., \& Kenny, D.A. (1986). The moderator-mediator variable distinction in social psychological research: Conceptual, strategic, and statistical considerations. Journal of Personality and Social Psychology, 51(6), 1173-1182. Retrieved from https://www.sesp.org/ files/The\%20Moderator-Baron.pdf

Carney, D. R., Jost, J. T., Gosling, S. D., \& Potter, J. (2008). The secret lives of liberals and conservatives: Personality profiles, interaction styles, and the things they leave behind. Political Psychology, 29(6), 807-840. Retrieved from https://www.psych.nyu.edu/ jost/Carney,\%20Jost,\%20\&\%20Gosling\%20(2008)\%20The\%20secret\%20lives\%20of\%20liber als\%20.pdf

Chamorro-Premuzic, T. (2007). Personality and individual differences. Oxford: Wiley Blackwell.

Constantine, M.G., Arorash, T.J., Barakett, M.D., Blackmon, S.M., Donnelly, P.C. \& Edles, P.A. (2001). School counselors' universal-diverse orientation and aspects of their multicultural counseling competence. Professional School Counseling, 5, 13-18. Retrieved from http://psycnet.apa.org/ record/2001-09030-003

Cohen, J., Cohen, P., West, S.G., \& Aiken, L.S. (2003). Applied multiple regression/correlation analysis for the behavioral sciences (3rd ed.). Mahwah, NJ: Erlbaum.

Crews, J., Smith, M., Smaby, M., Maddux, C., Torres-Rivera, E., Urbani, S., et al. (2005). Selfmonitoring and counseling skills: Skills-based versus interpersonal process recall training. Journal of Counseling \& Development, 83, 78-85. doi.org/10.1002/j.15566678.2005.tb00582.x

Çivitci, N. (2014). Miville-Guzman evrensellik-farklılık yönelimi ölçeği kısa formunun Türkçe'ye uyarlanması [The adaptation of short form of the Miville-Guzman universality-diversity scale 
into Turkish]. Ege Eğitim Dergisi-Ege Journal of Education, 15(1), 96-111. Retrieved from http://dergipark.gov.tr/download/article-file/57168

Dinesen, P. T., Klemmensen, R., \& Nørgaard, A. S. (2016). Attitudes towards Immigration: The role of personal predispositions. Political Psychology, 37(1), 55-72. https://doi.org/10.1111/ pops. 12220

Ekehammar, B. \& Akrami, N. (2003). The relation between personality and prejudice: A variable and a person-centred approach. European Journal of Personality, 17, 449-464. http://dx.doi.org/10.1002/per.494

Ekehammar, B. \& Akrami, N. (2007). Personality and prejudice: From big five personality factors to facets. Journal of Personality, 75(5), 899-925. https://doi.org/10.1111/j.14676494.2007.00460.x

Flynn, F. J. (2005). Having an open mind: The impact of openness to experience on interracial attitudes and impression formation. Journal of Personality and Social Psychology, 88(5), 816826. doi:10.1037/0022-3514.88.5.816

Frazier, P.A., Tix, A.P., \& Barron, K.E. (2004). Testing moderator and mediator effects in counseling psychology research. Journal of Counseling Psychology, 51(1), 115-34. http://dx.doi.org/10.1037/0022-0167.51.1.115

Fuertes, J.N., Miville, M.L., Mohr, J.J., Sedlacek, W.E., \& Gretcher, D. (2000). Factor structure and short form of the Miville-Guzman universality-diversity scale. Measurement and Evaluation in Counseling and Development, 33, 157-169. Retrieved from http://faculty.weber.edu/eamsel/Research\%20Groups/Diversity/Diversity\%20papers/Fuertes \%20et\%20al.\%20(2000).pdf

Gallego, A., \& Pardos-Prado, S. (2014). The big five personality traits and attitudes towards immigrants. Journal of Ethnic and Migration Studies, 40, 79-99. https://doi.org/10.1080/1369183X.2013.826131

Gerber, A. S., Huber, G. A., Doherty, D., Dowling, C. M., \& Ha, S. E. (2010). Personality and political attitudes: Relationships across issue domains and political contexts. American Political Social Review, 104, 111-133. https://doi.org/10.1017/S000305541000003

Han, S. \& Pistole, M.C. (2017). Big five personality factors and facets as predictors of openness to diversity. Journal of Psychology, 151(8), 752-766. doi:10.1080/00223980.2017.1393377.

Harbin, J. M. (2004). Counter transference reactions in a cross-racial dyad: The role of therapist universal-diverse orientation and presentation of client strengths experience (Doctoral thesis, University of Maryland, College Park, USA). Retrieved from https://drum.lib.umd.edu/bitstream/handle/1903/1528/umi-umd 1511.pdf? sequence= 1\&isAllowed $=\mathrm{y}$

Hirsh, J. B., DeYoung, C. G., Xu, X., \& Peterson, J. B. (2010). Compassionate liberals and polite conservatives: Associations of agreeableness with political ideology and moral values. Personality and Social Psychology Bulletin, 36, 655-664. Retrieved from http://individual.utoronto.ca/jacobhirsh/publications/Hirsh_DeYoung_Xu_Peterson_2010.pdf

Kail, R.V. \& Cavanaugh, J.C. (2008). Human development: A life-span view (5th edition). Belmont, CA: Wadsworth/ Cengage Learning.

Leong, F. T. L. \& Bhagwat, A. (2001). Challenges in "unpacking" the universal, group, and individual dimensions of cross-cultural counseling and psychotherapy: Openness to experience as a critical dimension. In D. B. Pope-Davis, \& H. L. K. Coleman (Eds.), The intersection of race, class and gender in multicultural Counseling (pp. 241-266). Thousand Oaks, CA: Sage.

McCrae, R. R., \& Costa, P. T. Jr. (1987). Validation of the Five-Factor Model of personality across instruments and observers. Journal of Personality and Social Psychology, 52, 81-90.

Retrieved fromhttp://webs.wofford.edu/steinmetzkr/teaching/Psy150/Lecture\%20PDFs/FiveFactorMo del.pdf 
McCrae, R. R. (2004). Conscientiousness. Encyclopedia of Applied Psychology, 1, 469-472. doi: 10.1016/b0-12-657410-3/00034-9

McCrae, R. R. \& Löckenhoff, C. E. (2010). Self-regulation and the five-factor model of personality traits. In R. H. Hoyle (Ed.), Handbook of Personality and Self-Regulation. (pp.145-168). Malden, MA: Blackwell.

Miville, M. L., Gelso, C. J., Pannu, R., Liu, W., Touradji, P., Holloway, P. \& Fuertes, J. N. (1999). Appreciating similarities and valuing differences: The Miville-Guzman universality-diversity scale. Journal of Counseling Psychology, 46 (3), 291-307. doi: 10.1037/0022-0167.46.3.291

Miville, M. L., Carlozzi, A. F., Gushue, G. V., Schara, S. L., ve Ueda, M. (2006). Mental health counselor qualities for a diverse clientele: Linking empathy, universal-diverse orientation, and emotional intelligence. Journal of Mental Health Counseling, 28(2), 151-165. http://dx.doi.org/10.17744// mehc.28.2.6khc06t87c2fr7y3

Mondak, J. J. (2010). Personality and the foundations of political behavior. New York: Cambridge University Press.

Moore-Thomas, C. (1998). Master's level of counselors' self-perceived multicultural competence: Relation to general counseling competence, conscientiousness, and openness to experience (Doctoral thesis, University of Maryland, College Park, USA). Retrieved from https://files.eric.ed.gov/fulltext/ED426328.pdf

Polat, S. (2009). Öğretmen adaylarının çok kültürlü eğitime yönelik kişilik özellikleri [Probationary teachers' level of inclination to multi-cultural education]. International Online Journal of Educational Sciences, 1(1), 154-164. https://www.researchgate.net/ publication/ 242552339_Ogretmen_Adaylarinin_Cok_Kulturlu_Egitime_Yonelik_Kisilik_Ozellikleri_Probatio nary_Teachers'_Level_of_Inclination_to_MultiCultural_Education

Ponterotto, J. G. (2008). Theoretical and empirical advances in multicultural counseling and psychology. In Brown S. D., Lent R. W. (Ed.), Handbook of counseling psychology (2nd edition). (pp. 121-140). Hoboken, NJ: John Wiley.

Robbins SP, Judge TA, Odendaal A, Roodt, G. (2009). Organisational behaviour. Global and Southern African Perspectives. Cape Town: Pearson.

Roberts, J. A., Laux, J. M., \& Burck, A. M. (2009). Exploring the relationship between universaldiverse orientation and personality. Journal of Counseling Practice. 1-7. Retrieved from http://www.ohiocounseling.org/Resources/Documents/ JCP\%20 Archives\%20PDF.pdf

Rolland, J.-P. (2002). Cross-cultural generalizability of the five-factor model of personality. In R. R. McCrae \& J. Allik (Eds.), The five-factor model of personality across cultures (pp. 7-28). New York: Kluwer Academic/ Plenum.

Shackeldford, Todd K., \& Avi Besser. (2007). Predicting attitudes toward homosexuality: Insights from personality psychology. Individual Differences Research, 5, 106-114. Retrieved from http://www.toddkshackelford.com/downloads/Shackelford-Besser-IDR-2007.pdf

Sibley, C. G., \& Duckitt, J. (2008). Personality and prejudice: A meta analysis and theoretical review. Personality and Social Psychology Review, 12, 248-79. https://doi.org/10.1177/1088868308319226

Stracuzzi, T.I., Mohr, J.J., \& Fuertes, J.N. (2011). Gay and bisexual male clients' perceptions of counseling: The role of perceived sexual orientation similarity and counselor universaldiverse orientation. Journal of Counseling Psychology, 58(3), 299-309. doi: 10.1037/a0023603.

Strauss, J.P., \& Connerley, M.L. (2003). Demographics, personality, contact, and universal-diverse orientation: An exploratory examination. Human Resource Management, 42, 159-174. https://doi.org/10.1002/hrm.10074

Thompson, R. L., Brossart, D. F., Carlozzi, A. F., \& Miville, M. L. (2002). Five-factor model (big five) personality traits and universal-diverse orientation in counselor trainees. The Journal of Psychology, 136(5), 561-572. http://dx.doi.org/10.1080/00223980209605551 
Trusty, J., Davis, P. E., \& Looby, E. J. (2002). Historical context of multiculturalism in the United States. In J. Trusty, E. J. Looby, \& D. S. Sandhu (Eds.), Multicultural counseling: Context, theory and practice, and competence (pp. 1-30). New York: Nova Science.

Turner, R. N., Dhont, K., Hewstone, M., Prestwich, A., \& Vonofakou, C. (2014). The role of personality factors in the reduction of intergroup anxiety and amelioration of outgroup attitudes via intergroup contact. European Journal of Personality, 28(2), 180-19. doi: 10.1002/per. 1927

Yeh, C.J. \& Arora, A.K. (2003). Multicultural training and interdependent and independent selfconstrual as predictors of universal-diverse orientation among school counselors. Journal of Counseling and Development, 81, 78-83. http://dx.doi.org/10.1002/j.15566678.2003.tb00228.x

Wang, Y., Davidson, M.M., Yakushko, O. F., Savoy, H. B., Tan, J. A. \& Bleier, J.K. (2003). The scale of ethnocultural empathy: Development, validation, and reliability. Journal of Counseling Psychology, 50, 221-234. http://dx.doi.org/10.1037/0022-0167.50.2.221

Weiten W. (2010). Psychology themes \& variations (8th ed.). Belmont, Wadsworth: Cengage Learning 


\section{Psikolojik Danışmanlık Öğrencilerinde Sorumluluk ve Dışadönüklük ile Evrensellik-Farklılık Yönelimi Arasındaki ilişskide Deneyime Açıklığın Düzenleyici Rolü}

\section{Prof.Dr. Nazmiye Çivitci}

Pamukkale Üniversitesi-Türkiye

ncivitci@pau.edu.tr

Özet:

Bu çalıșmanın amacı, psikolojik danışmanlık öğrencilerinde, sorumluluk ve dışadönüklük ile evrensellik-farklılı yönelimi arasındaki ilişkide deneyime açıkığın düzenleyici bir rolünün olup olmadığını test etmektir. Bu çalışma, Türkiye'nin batısında yer alan bir devlet üniversitesinde ögrrenim gören 377 psikolojik danışmanlık öğrencisi ile yürütülmüştür. Araştırma verilerini toplamak amacıyla Miville-Guzman Evrensellik-Farklılk Yönelimi Kısa Formu ve Sıfatlara Dayalı Kişilik Testi kullanılmıştır. Araştırmada sorumluluk ve dışadönüklük ile evrensellik-farklılık yönelimi arasındaki ilişkide deneyime açıklı̆ın düzenleyici etkisi, Baron ve Kenny'nin (1986) düzenleyicilik modeline ilişkin belirttikleri basamaklara dayalı bir dizi hiyerarşik çoklu regresyon analizi ile test edilmiştir. Araştırma sonucunda elde edilen bulgular, sorumluluk ve dışadönüklük ile evrensellik-farklılık yönelimi arasındaki ilişkide deneyime açılı̆̆ın düzenleyici etkisinin olduğunu göstermektedir. Buna göre, deneyime açılklk, sorumluluk ve dışadönüklügün evrensellik-farklılı yönelimi üzerindeki olumsuz etkilerini azaltarak bir tampon işlevi sergilemektedir.

Anahtar Kelimeler: Evrensellik-farklılk yönelimi, kişilik özellikleri, deneyime açıklık, sorumluluk, dışadönüklük

\section{E-Uluslararası Eğitim Araştırmaları Dergisi, Cilt: 11, Sayt: 2, 2020, ss. 1-15}

DOI: 10.19160/ijer.776966

\section{Önerilen Atıf}

Çivitci, N. (2020). Psikolojik danışmanlık öğrencilerinde sorumluluk ve dışadönüklük ile evrensellik-farklılık yönelimi arasındaki ilişkide deneyime açıkığın düzenleyici rolü, E-Uluslararası Eğitim Araştırmaları Dergisi, Cilt 11, Sayı 2, 2020, ss. 1-15, DOI: 10.19160/ijer.776966 


\section{GENIŞLETILMIŞ ÖZET}

Giriş: Toplumların gittikçe daha çoğulcu bir özellik kazanmasının psikolojik danışma alanına yansımaları da önem kazanmaktadır. Son yıllarda psikolojik danışma kuram ve uygulamalarında çoğulculuğun etkilerinin arttığı, psikolojik danışmanların farklılılara yönelik tutumları, farklı kültürlerden gelen danışanlar ile çalışma yeterliği gibi çok kültürlülüğe ilişkin konuların ilgi odağı olduğu gözlenmektedir. Farklııkları olan danışanlar ile çalışma yeterliğinin temeli insanlar arasında var olan benzerlik ve farklııkların farkına varılması ve kabul edilmesine dayalıdır (Yeh ve Arora, 2003). Psikolojik danışman, danışanın bireysel algı ve yaşantılarına olduğu kadar kolektif algı ve yaşantılarına da duyarlı olmalıdır (Trusty, Davis ve Looby, 2002). Bu bağlamda, insanlar arasında var olan benzerlik ve farklılıların farkına varılması ve kabul edilmesine ilişkin tutumları yansıtan evrensellik-farklılık yönelimi (Miville ve ark., 1999) önem kazanmaktadır. Evrensellikfarklıık yöneliminin, psikolojik danışmanların terapötik etkililiklerinde özellikle farklılıları olan danışanlarla etkili ilişkiler geliştirmede önemli bir rolü olduğu görülmektedir (Thompson, Brossart, Carlozzi ve Miville, 2002). Psikolojik danışma sürecinin etkililiğinde önemli rol oynayan diğer bir değişken ise psikolojik danışmanın kişilik özellikleridir. Psikolojik danışman eğitimcileri psikolojik danışma'nın etkililiğinde psikolojik danışmanın kişilik özelliklerini önemle vurgulamaktadırlar. Hatta, psikolojik danışmanların kişilik özelliklerinin danışanları ile ilişkilerinde kullandığı kuram ve tekniklerden daha etkili olduğu rapor edilmektedir (Crews ve ark., 2005). Psikolojik danışmanın terapötik etkililiğinde önemli bir rolü olan kişilik özelliklerinin evrensellik-farkllık yönelimine de katkıda bulunan bir değişken olduğu gözlenmektedir. Daha önce yapılmış olan bazı çalışmalar, psikolojik danışman adaylarında evrensellik-farklılk yöneliminin deneyime açıklık (Thompson, Brossart, Carlozzi ve Miville, 2002; Strauss ve Connerley, 2003), yumuşakbaşlllı (Strauss ve Connerley, 2003) ve sağlıklı kişilik özellikleri (Roberts, Laux ve Burck, 2005) ile pozitif yönde ilişkili olduğunu göstermektedir. Özellikle deneyime açıklık, evrensellik-farklılı yöneliminin güçlü bir yordayıcısı olarak (Thompson, Brossart, Carlozzi ve Miville, 2002) dikkat çekmektedir. Deneyime açılık, merak, entelektüel ilgi, bilişsel esneklik, yeni duygu ve düşüncelere açık olma eğilimini temsil etmektedir (Chamorro-Premuzic, 2007; Leong, 2008, s.723). Deneyime açık olanlar geniş bir ilgi alanına sahiplerdir (Rolland, 2002, s.8) ve estetik duyarlıkları yüksektir (Chamorro-Premuzic, 2007). Ayrıca, literatür incelendiğinde; deneyime açıklığın önyargı ile negatif yönde (Ekehammar ve Akrami, 2003; Flynn, 2005; Ekehammar ve Akrami, 2007), çok kültürlü psikolojik danışma yeterliği (Moore-Thomas, 1998), göçmenlere yönelik olumlu (Gallego ve Pardos-Prado, 2013) ve eşitlikçi tutumlar (Ackermann ve Ackermann, 2015) ile pozitif yönde ilişkili olduğu görülmektedir. Deneyime açıklığın bu özellikleri, farklılıklara yönelik olumlu tutumlara işaret etmektedir ve evrensellik- farklılı yöneliminin güçlü bir yordayıcısı olmasını açıklamaktadır. Ayrıca, Dinesen, Klemmensen ve Norgaard (2016) tarafindan yapılan araştırmada elde edilen bulgular, deneyime açıklığın, göçmenlere yönelik tutumlar üzerinde kültürel ve ekonomik tehdit gibi faktörlerin etkisini azaltarak göçmenlere yönelik tutumlara olumlu katkılarının olduğunu göstermektedir. Bu bulgu, deneyime açıklığın, farklııklara yönelik tutumlar üzerinde doğrudan etkilerinin yanı sıra dolaylı etkilerini de ortaya koymaktadır. Deneyime açıklığın, farklılıklara yönelik tutumlar üzerindeki olumlu etkileri, psikolojik danışmanlar için önemini artırmaktadır. Deneyime açıklı, özellikle, psikolojik danı̧̧manların, psikolojik danışma ilişkisinde ırk ve cinsiyet gibi farkllıklara ilişkin durumları yönetme yeteneği için temel bir boyut olarak kabul edilmektedir. (Leong ve Bhagwat 2001). Kişilik faktörleri arasında farklılılara yönelik en güçlü ve tutarlı olumlu ilişkinin deneyime açıklık olduğu gözlenmektedir. Sorumluluk ve dışadönüklük ise deneyime açıklığın aksine farklılılara yönelik olumsuz tutumları ile dikkat çeken kişilik özellikleridir. Deneyime açıklığın farklılıklara yönelik olumlu tutumlar ile arasındaki güçlü ilişki göz önüne alındığında, sorumluluk ve dışadönüklügün farklılılara yönelik tutumlar üzerindeki olumsuz etkilerini azaltarak bir tampon işlevi görmesi beklenebilir. Bu çalışmanın amacı, psikolojik danışmanlık öğrencilerinde, sorumluluk ve dışadönüklük ile evrensellik-farkllık yönelimi arasındaki ilişkide deneyime açıklığın düzenleyici bir rolünün olup olmadığını test etmektir. 
Yöntem: Bu çalışma, Türkiye'de bir devlet üniversitesinde öğrenim gören 268'i klz, 109'u erkek olmak üzere 377 psikolojik danışmanlık lisans öğrencisi ile gerçekleştirilmiştir. Yaşları 18-25 arasında değişen katılımcıların yaş ortalaması ise 20.38'dir. Araştırma verilerini toplamak amacıyla Miville-Guzman Evrensellik-Farklıık Yönelimi Kısa Formu ve Sıfatlara Dayalı Kişilik Testi kullanılmıştır. Araştırmada sorumluluk ve dışadönüklük ile evrensellik-farklılk yönelimi arasındaki ilişkide deneyime açıklı̆ın düzenleyici (moderatör) etkisi, Baron ve Kenny'nin (1986) düzenleyicilik modeline ilişkin belirttikleri basamaklara dayalı bir dizi hiyerarşik çoklu regresyon analizi ile test edilmiştir.

Bulgular: Analiz sonucunda elde edilen bulgulara göre sorumluluk ile deneyime açıklık etkileşimi $[\beta=0.11, p<.01]$ ve dışadönüklük ile deneyime açıklık etkileşimi $[\beta=0.12, p<.01]$ evrensellikfarklılık yönelimini anlamlı olarak yordamaktadır. Buna göre, deneyime açıklı, hem sorumluluk ile evrensellik-farklılk yönelimi hem de dışadönüklük ile evrensellik-farklılı yönelimi arasındaki ilişkide düzenleyici (moderator) bir rol oynamaktadır. Diğer bir deyişle, deneyime açılık düzeyi düşük olan ögrrencilerde, sorumluluk ve dışadönüklük arttıkça evrensellik-farklılk yönelimi düzeyi düşmektedir. Ancak, deneyime açıklık düzeyi yüksek olan öğrencilerin evrensellik-farklıık yönelimi düzeylerinde böyle bir azalma gözlenmemektedir.

Tartışma: Bu araştırmada, psikolojik danışmanlık öğrencilerinde, sorumluluk ve dışadönüklük ile evrensellik-farklılık yönelimi arasındaki ilişkide deneyime açıklığın düzenleyici rolü incelenmiştir. Araştırma sonucunda elde edilen bulgular, psikolojik danışmanlık ögrencilerinde sorumluluk ve dışadönüklük ile evrensellik-farklılı yönelimi arasındaki ilişkide deneyime açıklı̆ın düzenleyici etkisinin olduğunu göstermektedir. Buna göre, deneyime açıklık, sorumluluk ve dışadönüklügün evrensellik-farklılık yönelimi üzerindeki olumsuz etkilerini azaltarak bir tampon işlevi sergilemektedir. Deneyime açıklığn, farklılılara yönelik daha esnek ve kabul edici tutumlar geliştirilmesini kolaylaştırıcı bir rolünün olduğu söylenebilir. Araştırma sonuçlarının, danışman eğitimi açısından da doğurguları bulunmaktadır. Psikolojik danışmanlık öğrencilerinin, kişilik özelliklerinin farklııklara yönelik tutumlarına katkısına ilişkin farkındalık geliştirmelerinin kendilerini keşfetmeleri ve iç görü kazanmalarında etkili olacağı düşünülmektedir. Farkındalık geliştirmelerinde danışman eğitimindeki deneyimleri; özellikle psikolojik danışma süpervizyon sürecinde, kişilik özelliklerinin farklııklara yönelik tutumlarına nasıl yansıdığına ilişkin farkındalık kazandıracak yaşantılara yer verilmesi önemli görülmektedir. 